\title{
Intra- and inter-organizational tensions of a digital servitization strategy. Evidence from the mechatronic sector in Italy
}

\author{
Serena Galvani and Roberta Bocconcelli \\ Department of Economics, Society and Politics (DESP), University of Urbino Carlo Bo, Urbino, Italy
}

\begin{abstract}
Purpose - This paper aims to analyze the digital servitization (DS) process with the paradox theory lens. The purpose is to catch how intra- and inter-organizational tensions generate complexity along a DS journey to find "where" and "when" industrial companies can intervene to face them. Design/methodology/approach - The methodology is a qualitative, in-depth single case study, which longitudinally explores the DS strategy of a manufacturer along with three phases of development: design, implementation and assessment.

Findings - The analysis reveals six intra- and inter-organizational tensions in DS and provides insights on tensions' origin and how to face them. A theoretical framework on DS complexity and an empirical framework on tensions' origin is produced.

Originality/value - The research combines service and organizational paradox literature. Together with a longitudinal methodology, it results in a spatial and temporal analysis of DS, from which theoretical and managerial implications are drawn.
\end{abstract}

Keywords B2B, Complexity, Tensions, Paradox theory, Digital servitization

Paper type Research paper

\section{Introduction}

The business-to-business (B2B) context is experiencing a business model revolution toward the digital servitization strategy (DSS). B2B firms are massively engaged in digital servitization (DS) shifting. The $60 \%$ of industrial companies that have already undergone a digital transformation created new business models. In 10 years, $30 \%$ of revenues will come from digital projects, half of them involving new "outcomes/ solutions" (Morgan, 2019; Wellener et al., 2020).

A DSS generates complexity for industrial firms. Challenges are identified at the intra- and inter-organizational levels (Tronvoll et al., 2020). Industrial companies chasing a DSS rethink the intra-organizational dynamics, adapt knowledge and capabilities, structure leadership and hierarchy. At the same time, they review the inter-organizational processes and reinforce network relationships by accessing service ecosystems, adjusting interdependencies in the supply chain and intensifying relationships with customers (Bustinza et al., 2018; Ruiz-Alba et al., 2019).

Intra- and inter-organizational impacts of a DSS can foster the development of paradoxical tensions (Vendrell-Herreo et al., 2017; Harini and Thomas, 2020). Tensions as ambidexterity/ambivalence, territoriality or the risk of service paradox result from servitizing activities (Lenka et al., 2018; Wagstaff et al., 2021; Gebauer et al., 2005). The paradox theory can help in capturing the complexity involved in

The current issue and full text archive of this journal is available on Emerald Insight at: https://www.emerald.com/insight/0885-8624.htm

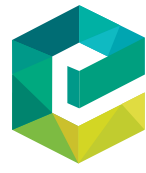

Journal of Business \& Industrial Marketing 37/13 (2022) $1-18$

Emerald Publishing Limited [ISSN 0885-8624] [DOI 10.1108/JBIM-03-2021-0183] business strategies and it has recently been adopted to describe servitization dynamics (Kohtamäki et al., 2020; Wagstaff et al., 2021; Burton et al., 2016).

Notwithstanding the growing interest toward a paradox perspective on servitization, few studies address it in the context of DS (Kohtamäki et al., 2020; Altmann and Linder, 2019). The digital component of servitizing strategies needs further analysis as it has been acknowledged as facilitating or hindering some processes that require new skills and changes within the network actors (Matthyssens, 2019; Salo et al., 2021).

Notably, the opportunity to further investigate DSS through a paradoxical perspective is twofold. It allows to fill a gap in academic DS studies and it provides a concrete tool to facilitate DS implementation by managers. Understanding the nature of intra- and inter-organizational tensions of a DSS and their implications constitutes critical sparks for firms investing in it. A paradox theory approach can provide managers with indepth knowledge of DS challenges and possible ways to address them effectively and reach better performances.

For such reasons, this paper investigates how manufacturing firms face their transitioning toward a DSS, adopting the paradox theory lens to gain insights on intra- and

(C) Serena Galvani and Roberta Bocconcelli. Published by Emerald Publishing Limited. This article is published under the Creative Commons Attribution (CC BY 4.0) licence. Anyone may reproduce, distribute, translate and create derivative works of this article (for both commercial and non-commercial purposes), subject to full attribution to the original publication and authors. The full terms of this licence may be seen at http://creativecommons.org/licences/by/4.0/legalcode

Received 30 March 2021

Revised 26 August 2021

25 October 2021

Accepted 3 November 2021 
inter-organizational tensions. Notably, the paper aims to answer the following research questions (RQs):

RQ1. How does the emergence of intra- and interorganizational tensions generate complexity along a DSS?

RQ2. Where and when can manufacturing companies intervene to dissolve such complexity?

By answering the RQs, the paper contributes to building new knowledge on DS. Notably, the paper adds insights into the role of intra- and inter-organizational circumstances in increasing the complexity of the DS journey. In this respect, tensions and new challenges for companies aiming at developing a DSS emerge with respect to previous literature. Important managerial implications are drawn; remarkably, strategic approaches to DS are provided at every stage of the DSS. In general terms, findings reveal the relevance of analyzing DS taking a holistic overview of its tensions and of adopting an "iterative approach" in developing solutions.

The remainder of the paper is organized as follows. Section 2 addresses the literature background and introduces a theoretical framework to disentangle DS complexity. Section 3 concerns the applied methodology. Section 4 introduces the case study and the main findings of the research. Section 5 presents the critical discussions of results. Section 6 provides concluding remarks, managerial implications of the study, limitations and future research suggestions.

\section{Literature review}

\subsection{A paradox theory approach to services}

Paradoxes are "contradictory yet interrelated elements (dualities) that exist simultaneously and persist over time; such elements seem logical when considered in isolation, but irrational, inconsistent, and absurd when juxtaposed" (Smith and Lewis, 2011, p. 387). In the case of a paradox, every choice seems inappropriate.

Paradoxes appear in various contexts and phenomena; this study focuses on paradoxes emerging from managerial actions. The higher expectations of markets, the increased number and variety of stakeholders and the quick pace of change of the business environment are pushing B2B companies toward new managerial paradoxes, especially in case of scarce resources and intense competition (Heidrick and Struggles, 2015).

Paradoxical literature in management mainly focused on the organizational level of analysis, trying to conceptualize managerial issues as paradoxes or organizational tensions (Putnam et al., 2016; Smith and Lewis, 2011). In these studies, a variety of levels has been explored, such as tensions in human resource management, leadership, identity, creativity, teams, gender and diversity, sustainability or innovation (Waldman et al., 2019).

In the service field, paradoxes have been identified in relation to servitization strategies, which imply a service-oriented business model for manufacturers (Baines and Lightfoot, 2013). At the intra-organizational level, examples of paradoxes are the "service paradox" (Gebauer et al., 2005), which is the risk of having servitization expenditures higher than returns or the organizational ambivalence between product and service orientation (Lenka et al., 2018; Ashforth et al., 2014). Taking the inter-organizational layer, Burton et al. (2016) found empirical evidence for tensions in the service network, as servitizing firms try to appropriate value from other actors. The unpredictability deriving from servitization generates tensions in collaborating with external actors, sharing knowledge assets, balancing between proactivity and adaptation, managing different commitment levels and territorial behaviors (Colm et al., 2020; Wagstaff et al., 2021). Kohtamäki et al. (2020) identify paradoxes connected to customization levels and engineering efficiency, service organizational structure and innovation.

\subsection{Digital servitization strategies}

The digital wave experienced from 2013 on, renamed as Industry 4.0 revolution, involves manufacturers toward DSS (Coreynen et al., 2017). Unlike servitization strategies, DSS exploits digitalization to introduce advanced, technology-based services (Bustinza et al., 2018). A DSS implies a complex change for industrial firms, where a product-centric business model is redesigned through a digital service-centric approach (Tronvoll et al., 2020). Manufacturers investing in DSS focus on digitalized customers solutions, with the aim of achieving higher returns and enlarging their customers' portfolio (Matthyssens and Vandenbempt, 2008).

Notwithstanding the opportunities a DSS can offer for industrial firms, it implies difficulties (Martìn-Peña et al., 2019; Paiola and Gebauer, 2020; Coreynen et al., 2017). From nearly 2010 on, literature about DS deeply explores such problems referring to intra- and inter-organizational challenges (Sjödin et al., 2019; Frank et al., 2019).

Intra-organizational implications of DS are challenges in the managerial, internal organization (Bustinza et al., 2018); difficulties are identified in acquiring knowledge and capabilities to face a DSS, achieving convergence between digital and service innovation trajectories, as well as between the product and the service orientation, aligning the value system position and the sales model to the DSS (Bustinza et al., 2018; Hasselblatt et al., 2018; Frank et al., 2019; Lenka et al., 2018; Paiola and Gebauer, 2020).

DS also impacts the relationship with customers, suppliers and other stakeholders; the inter-organizational level of analysis assumes high relevance (Vargo and Lusch, 2011; VendrellHerreo et al., 2017). Interorganizational challenges of a DSS include difficulties in managing relationships with old and new actors, elaborating value co-creation processes with customers, distinguishing customers interested in advanced services to invest financial and technological resources (Sjödin et al., 2020; Reim et al., 2018; Grandinetti et al., 2020).

The combined analysis of the intra- and inter-organizational dynamics of a DSS is required to catch the complexity of the phenomenon. As argued by Coreynen et al. (2017), a DSS is made of two organizational perspectives: the back-end perspective, involving operational efficiency, availability of resources and decision-making processes and the front-end, about interactions with customers and network integration.

Paradoxes in DS have not been fully investigated yet, even though authors address the issue (Kohtamäki et al., 2020). In our perspective, analyzing DSS through the paradox theory lens offers a deeper knowledge of DS complexity, as the digital 
dimension can intricate the servitization journey in presence of specific external and internal conditions. This study aims at providing a theoretical model for the interpretation of tensions in DSS, which is introduced in the following section.

\subsection{A theoretical framework for digital servitization tensions}

DS is a complex journey, made of continuous challenges and timely choices with impacts at the intra- and interorganizational level (Struyf et al., 2021). At the same time, paradoxes in management research need a multilevel analysis to be fully exploited (Waldman et al., 2019). Therefore, the proposed theoretical framework (Figure 1) for the investigation of DSS tensions is structured around a double level of analysis, intra- and inter-organizational, to provide a complete understanding of the phenomenon.

The framework combines intra- and inter-organizational challenges imposed by DS with firm-specific circumstances: such elements together potentially give rise to tensions. It is based on the idea that the complexity of the servitizing process is increased by the presence of double-level challenges and circumstances, which foster the creation of tensions throughout the entire strategy development. For instance, integrating product and service orientations (challenge) could generate organizational tensions about the leadership model and hierarchical structure needed to limit resistances, especially in the case of a strong product-centric identity (circumstance).

To verify the validity of the framework the paper adopts an original perspective. The study is based on the in-depth analysis of a firm involved in a DSS. The entire project is built around the industrial internet of things (IIoT) technology and its multifaceted applications. The adopted longitudinal perspective highlights time- and space-related elements of the DSS, while a dual perspective, intra- and inter-organizational, completes the investigation of the phenomenon.

\section{Research methodology}

\subsection{Research design}

The applied method is a longitudinal, in-depth single case study, with an abductive approach to code information and elaborate results (Dubois and Gadde, 2002). A single case study is relevant to build knowledge on under-investigated phenomena and get the complexity levels involved in the inquired relationships (Halinen and Törnroos, 2005). The chosen methodology depends on the contemporary events and the "how" nature of the RQs. It is justified by the need to explore concepts, evaluate the role of context and history and achieve a greater level of detail of the phenomenon (Yin, 2009; Meyer, 2001; Lindgreen et al., 2020).

The case firm, Alpha, is a mechatronic manufacturer located in Italy. In 2016, the company invested in a five-year project of DS by implementing an IIoT-based platform called Aura. The project will be completed in one year and it is developed in partnership with the consultancy agency Innoconsulting [1].

Specific criteria explain the choice of the company:

- the firm operates in a B2B context;

- it is involved in a DSS - the ongoing status of the strategy helps to have accurate data as respondents' information are not influenced by unperfected memories (Lindgreen et al., 2020); and

- the company extends the DSS to an international reference market.

Given the research purpose, a sample "theoretical and purposeful [...] and guided by saturation" is relevant (Gummesson, 2003, p. 488): Alpha is a successful digital servitizing firm and other cases are likely to add similar information.

The empirical research has been guided by literature. The DSS theoretical framework is the starting point to design data collection and analysis. Data has been continuously compared with information collected in literature to evaluate the validity of the framework.

\subsection{Data collection}

The firm has been observed for five years. The active observation happened from January 2019 until December 2020, while preceding years have been observed retrospectively. Data collection relies on two sources: participating observations and semi-structured interviews. Participating observations amount to $193.5 \mathrm{~h}$ in the timeframe January 2019 - December 2020,

Figure 1 Theoretical framework for DSS tensions

\begin{tabular}{|c|c|c|c|}
\hline \multicolumn{2}{|c|}{ INTRAORGANIZATIONAL LEVE } & \multicolumn{2}{|c|}{ INTERORGANIZATIONAL LEVE } \\
\hline CHAUENGES & GIRCUMSTANCES & CHAШENGES & GRCUMSTANCES \\
\hline $\begin{array}{l}\text { - Build highly specialized knowledge and } \\
\text { capabilities for DS } \\
\text { - Achieve convergence between the digital and } \\
\text { service innovation trajectories of the DSS } \\
\text { - Aign the value system to the DSS } \\
\text { - Adapt the sales model to the DSS } \\
\text { - Establish innovative structures and cultural } \\
\text { openness } \\
\text { - Manage big data } \\
\text { - Integrate product and service orientation }\end{array}$ & $\begin{array}{l}\text { - Scarse resources } \\
\text { - Information asimmetries } \\
\text { - Oltural resistances } \\
\text { - Lack of capabilities and competences } \\
\text { - Uncertain leadership } \\
\text { - Product-centric identity }\end{array}$ & \begin{tabular}{|l|} 
- Manage network relationships for the DSS \\
- Co-create value with customers in the design \\
of digital services \\
- Recognize financial and technological \\
readiness of customers for digital services \\
- Oreate multi-actor partnerships underpinned by \\
trust \\
- Improve strategic position in the value chain \\
- Exploit provider-customer relationships to \\
maximize DS benefits
\end{tabular} & $\begin{array}{l}\text { - Inefficient supply chain management } \\
\text { - Limited collaboration with customers } \\
\text { - Technologically underdeveloped environment } \\
\text { - Lack of a collaborative business network } \\
\text { - Oustomers' scepticism on digital tools } \\
\text { - High competition } \\
\text { - Low-power position in the value chain }\end{array}$ \\
\hline \multicolumn{2}{|c|}{$\begin{array}{l}\text { References: Bustinza et al. (2018), Hasselblatt et al. (2018), Frank et al. (2019), Lenka et al. (2018), } \\
\text { Paiola and Gebauer (2020), Tronvoll et al. (2020) }\end{array}$} & \multicolumn{2}{|c|}{$\begin{array}{l}\text { References: Sjödin et al. (2020), Reim et al. (2018), Grandinetti et al. (2020), Vaittinen and } \\
\text { Martinsuo (2019), Tronvoll et al. (2020), Kamalaldin et al. (2020) }\end{array}$} \\
\hline \multicolumn{2}{|c|}{ INTRAORGANIZATIONAL TENSIONS } & \multicolumn{2}{|c|}{ INTERORGANIZATIONAL TENSIONS } \\
\hline
\end{tabular}


distributed between 77 activities (see Appendix, Table A1 for details). They include different activities involving the service function: meetings, presentations, conferences and others, mirroring in percentages their totality. As observations were causal in nature, no formal protocol has been elaborated (Yin, 2009); the collected field notes were consulted and confronted with interviews' transcriptions.

After the first year of observations, interviews started to integrate data collected through the observations, triangulate information, reduce biases and validate findings (Jonsen and Jehn, 2009). Interviews were semi-structured, to guide the direction of the discussed topics. An interview protocol was designed (see Appendix, Table A2 for details) to collect focused data, standardize the interview approach and maintain flexibility (Hunter, 2012). The protocol is based on literature insights and on the RQs of the study. It revealed purposeful to identify respondents, retrace the DSS and recognize intra- and inter-organizational tensions. The protocol involves three thematic sets of questions: about the respondents, about the service area and the DSS and about the implications of the DSS. Similar questions were raised to all respondents, even though adapted for specific roles. Respondents were provided with total freedom to answer questions and no direct connection to paradoxes or tensions was prompted, to avoid "biased researcher's opinion" (Thirsk and Clark, 2017).

Interviews were conducted in the timeframe October 2019 August 2020. Interviewees are significant persons in the DSS: they directly contributed to the deployment of the strategy and participated (nearly) from its beginning. They are more representative figures in the DS journey than the average (Yin, 2009). Table 1 shows interviews details.

To delineate the case context and implications, secondary sources have been used: the company website - and the website of other actors involved in the project - sectorial magazines/editorials, press briefings and corporate reports. Results are described in temporal order, highlighting the timeline in which the tensions emerged to guarantee clarity (Sandelowski, 1999).

\subsection{Data analysis}

To answer the RQs, the DS process was retraced iteratively. Findings are the outcome of a continuous interrelation and triangulation between the perspectives captured through interviews, observations and secondary sources (Denzin, 1978). Going back and forth between the analyzed literature and case findings provides a complete view of the DS and its context to build theoretical considerations (Dubois and Gadde, 2002).

Data analysis followed the theoretical framework: information was explored to identify DS challenges and intrinsic circumstances intriguing the DS path of Alpha. Attention was, thus, posed to distinguish the nature of challenges and circumstances if intra- or inter-organizational (Figure 1). In doing this, a coding process (Figure 2) was activated to structure data, elaborate the case tensions and identify their origins.

The first coding step was creating categories from data collected through participating observation notes. Categories were assigned labels in the form of short sentences, using as much as possible the lexicon adopted by the informants. Duplicates were removed; the resulting 53 categories include challenges and circumstances of the firm DSS. Afterward, categories were condensed into 12 tensions components. Finally, 6 themes have been identified that aggregate the components of the tensions. Every theme represents a tension and every tension component stands for its two alternative options. No software was needed to code information given the simplified data structure typical of single case studies (Lindgreen et al., 2020). This coding procedure allowed to detect intra- and inter-organizational connections and the emergence of tensions causing increasing complexity in DS, in line with the adopted theoretical approach.

Table 1 Interviews data

\begin{tabular}{|c|c|c|c|c|}
\hline Respondent's information & Date & $\begin{array}{l}\text { Duration of } \\
\text { interview }\end{array}$ & Main research topic & $\begin{array}{c}\text { Transcription } \\
\text { length } \\
\text { (\# of pages) }^{\text {a }}\end{array}$ \\
\hline $\begin{array}{l}\text { Service Innovation Director - Alpha Group } \\
\text { Working in Alpha Group since } 2017 \text { (4 years) }\end{array}$ & $29 / 10 / 2019$ & $45^{\prime}$ & $\begin{array}{l}\text { Relevance of services and new } \\
\text { investments }\end{array}$ & 5 \\
\hline $\begin{array}{l}\text { CEO Assistant for Innovation - Alpha Group } \\
\text { Working in Alpha Group since } 2012 \text { ( } 9 \text { years) }\end{array}$ & $08 / 11 / 2019$ & $50^{\prime}$ & Impacts of Service innovation process & 5 \\
\hline $\begin{array}{l}\text { Senior Project Manager - Innoconsulting } \\
\text { Collaborating with Alpha Group since } 2016 \text { ( } 5 \text { years) }\end{array}$ & $14 / 11 / 2019$ & 50 & Idea, design and development of Aura & 7 \\
\hline $\begin{array}{l}\text { Aura Ambassador - Alpha Group } \\
\text { Working in Alpha Group since } 2019 \text { ( } 2 \text { years) }\end{array}$ & $22 / 11 / 2019$ & $40^{\prime}$ & $\begin{array}{l}\text { Management of Aura renewal and } \\
\text { contact with customers }\end{array}$ & 4 \\
\hline $\begin{array}{l}\text { Aura Project Manager - Alpha Group } \\
\text { Working in Alpha Group since } 2018 \text { ( } 3 \text { years) }\end{array}$ & $25 / 11 / 2019$ & $55^{\prime}$ & $\begin{array}{l}\text { Issues and criticalities in the } \\
\text { development of Aura }\end{array}$ & 4 \\
\hline $\begin{array}{l}\text { Marketing Official - Alpha Group } \\
\text { Working in Alpha Group since } 2007 \text { (14 years) }\end{array}$ & $10 / 12 / 2019$ & $45^{\prime}$ & Communication of Aura & 4 \\
\hline $\begin{array}{l}\text { CEO Assistant for Innovation - Alpha Group } \\
\text { Working in Alpha Group since } 2012 \text { ( } 9 \text { years) }\end{array}$ & $31 / 07 / 2020$ & $40^{\prime}$ & $\begin{array}{l}\text { Organizational issues in Service } \\
\text { innovation }\end{array}$ & 3 \\
\hline $\begin{array}{l}\text { Maintenance Manager - Alpha Group's Customer } \\
\text { Collaborating with Alpha Group since } 2017 \text { (4 years) }\end{array}$ & 05/08/2020 & $40^{\prime}$ & Customer perspective about Aura & 3 \\
\hline
\end{tabular}


Figure 2 Coding scheme

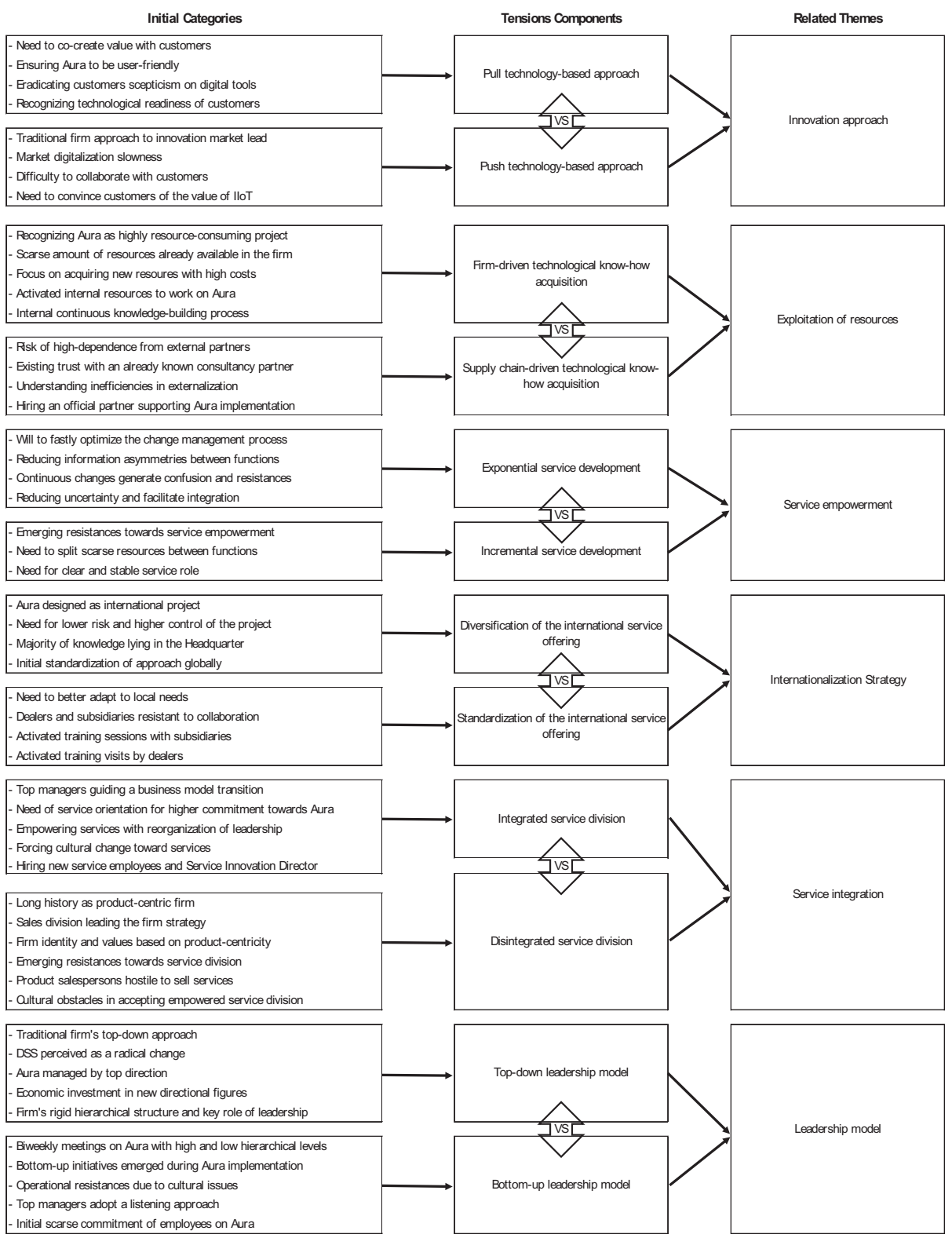

\section{Findings}

Alpha is a B2B company specialized in the production of industrial wood-working machinery in the furniture sector. Being a family-run company, Alpha experienced considerable growth. Today it operates worldwide with nearly 4,000 employees and its revenues amounted to over $900 \mathrm{~m}$ euros in 2020 .

In 2016, Alpha invested in a DSS by implementing sensors to the produced machineries, which monitor their activities by customers and generate real-time information. The IIoT project is called Aura, which indicates Alpha's service platform launched in collaboration with the consultancy partner Innoconsulting. Aura provides services as key performance indicator, preventive maintenance and error notifications, video remote assistance, maintenance calendar or contracts purchase.
The DSS of Alpha happened in three temporal phases: project design, implementation and assessment. The design stage involved shaping the DS idea and defining its technical features; the implementation stage was about technical and organizational developments at the international level; the assessment stage concerned adjustments on the platform and the development of additional features. The latter is not concluded yet.

\subsection{Project design}

At the beginning of 2016, Alpha decided to invest in a DSS. It aimed at responding to market dynamism and gaining competitive advantage by a first-mover strategy. To accomplish such an aim, recognizing the financial and technological readiness of customers for digital services was as relevant as 
complex. Relevance concerned establishing the type of technology to make Aura valuable and user-friendly. Complexity was generated by the company's limited experience in co-creating value with customers and the digitalization slowness of many of them. Such situation triggered a tension:

\section{T1: Pull vs Push technology-based innovation}

A cooperative, pull innovation fosters the adoption of technologies, which are familiar and of value for customers, while answering the collaborative call of DS. A push technology-based approach, instead, embraces the core innovative modus operandi of Alpha, with apparently reduced complicacy.

The need to engage customers collided with Alpha's approach, characterized by innovation market lead, with limited customer involvement. The firm adopted a push technology-based approach to innovation:

"Customers were not essential in deciding if to invest in digital servitization [...] they were totally in the dark about IIoT technology and its potentiality [...] maybe a few big customers were starting to consider new technologies, but nothing more [...]" [CEO Assistant for Innovation - Alpha].

They implemented a DSS based on the IIoT technology for the supply of product-service systems solutions via computer, smartphone and tablet applications.

Once the technology was established, its implementation required the planning of resources, competencies and actors. The choice of developing the technology internally rather than turning to external suppliers ended up being a tension:

\section{T2: Firm-driven vs Supply chain-driven technological} know-how acquisition

Alpha's challenge was achieving IIoT-specialized capabilities, as the ability to exploit big data, to protect the DS competitive advantage:

"A DS barrier for us is the development of competencies to analyze big data coming from machines and manage them through dedicated functions [...]" [Service Innovation Director-Alpha].

Specialized DS knowledge available inside the firm was limited, as well as human resources to commit to Aura. The necessity to cooperate along the supply chain emerged:

"Most parts of the required competencies to implement the project were to be found on the outside [...] Alpha needed to work on the integration of new competencies through innovation along the supply chain to guarantee the technological advancements of the entire industry" [Service Innovation Director-Alpha].

Frictions arose between top managers; they recognized a lack of resources in their teams but manifested some hesitancy in relying on external actors. The involvement of an external supplier meant directly accessing qualified competencies but also reducing process control and limiting the development of internal knowledge. Moreover, Alpha was operating in a highly competitive market, where multi-actor partnerships were not excited and collaborative approaches inhibited. Nevertheless, preceding collaborations with the consultancy agency Innoconsulting made it a trusted supplier. This relationship facilitated the solution of the tension: Alpha nominated Innoconsulting official partner for Aura:

\footnotetext{
"We had no doubt that a company of that size and capacity [Innoconsulting] would have accompanied us not only in the technical part but in the business and change management [...] and so it was" [CEO Assistant for Innovation-Alpha].
}

The participation of Innoconsulting in the project revealed paramount. However, Alpha engaged resources and spread knowledge capital between managers and employees inside the firm to reduce the risk of dependence from its partner.

\subsection{Project implementation}

In July 2016, a pilot session of Aura was performed; positive results pushed Aura implementation. For Aura to be launched in the market, a reorganization of Alpha's service function was required. The function was not structured enough to lead the DSS independently. The top management should decide whether to invest in the fast growth of the service function or to draw resources from other divisions and expand the service function gradually. This choice transmuted into a tension:

\section{T3: Exponential vs Incremental service development}

The firm strived for equal distribution of power between divisions and consequent service empowerment, with the optimized control of the change management process:

"What we tried to do was creating a new business model more oriented towards services, but in harmony with the firm identity" [Aura Project Manager-Alpha].

The limited willingness of resources called for incremental service development. It gives employees time to adapt to the revisited organizational structure. At the same time, swift service growth should facilitate the DSS implementation because of the application of stable roles and clear responsibilities.

The firm opted for incremental service empowerment. Unexpectedly, resistances emerged due to the continuous changes and adaptations of the service strategy. The slow, unsure extension of functionalities, professional figures, tools and procedures in service, generated confusion and resistances, revealing information asymmetries between functions.

In November 2016, Aura was delivered to customers in Italy. In nearly one year, it was distributed also worldwide through the group's network: subsidiaries and dealers. During Aura's internationalization, technological advancements were settled and the international digital service offering was designed. A new tension emerged:

\section{T4: Diversification vs Standardization of the international service offering}

Alpha's challenge was to provide customers with a flexible service offering adaptable to local needs. Therefore, diversification was suitable. Some circumstances obstructed its realization. Limited resources, information asymmetries, subsidiaries and dealers' lack of DS knowledge entailed a standardized approach. Contextually, Italian customers showed hesitant responses to the service offering. Alpha missed the ability to collaborate with customers and eradicate skepticism on digital tools.

The first solution to T4 was standardization. The headquarter centralized decisions: it arranged tools and infrastructures, communication plans and the go-to-market strategies for every country. In 2019, issues with subsidiaries and dealers started. Subsidiaries perceived a lack of DS competencies, while dealers interpreted Aura as a threat of channel cannibalization. Moreover, Aura faltering performances internationally revealed customers' apathy about digital services: 
"Many customers, especially the small ones, do not catch the potential of Aura and the advantages that it can bring in the long term [...] they perceive new services just as a cost [...]" [Aura Ambassador-Alpha].

Top managers were pushed toward a reconsideration of their choices. Flexibility to subsidiaries was enhanced by the design of local service packages and contracts. Local visits and training sessions with subsidiaries and dealers improved the collaboration: "We need to achieve a higher level of flexibility for subsidiaries [...] we will
intensify training sessions and transfer knowledge about Aura on
subsidiaries [...]" [Foreign Branch Manager-Alpha].

\subsection{Project assessment}

From 2019 on, Alpha managed the Aura assessment. The firm promoted initiatives trying to solve issues raised by T3 and T4. Internal communication actions about Aura were implemented. A new organizational figure was introduced with the role of connector between sales, service and IT. Internal workgroups were established to facilitate cross-collaboration between sales, marketing and service. Ad-hoc rewards were introduced for service salespersons based on selling indicators. Marketing campaigns stimulated Aura's discovery toward customers.

Concurrently, a tension emerged about the relationship between service and other functions:

\section{T5: Integrated vs Disintegrated service function}

Top management longed for the integration of the service function within the organization to stimulate efficiency and inter-functional synergies, especially on the commercial side. Vision, objectives and resources alignment between functions help reach customer engagement in the aftersales and before. Nevertheless, service integration is risky, as it partially destroys the group's values, residing in machines offering and productcentricity.

Top management strived for service integration. It helps reach a less product-oriented mindset, innovate the hierarchical structure and establish cultural openness in terms of (digital) services. Cultural resistances in the commercial area contrasted this vision:

"The fact that Aura is an intangible product means that the commercial network did not see its saleability [...] commercials are used to seeing, talking about, and selling just physical assets [...] this is a completely different business model" [Aura Project Manager-Alpha].

Resistances in the product function, which concentrated power and strategic relevance, extended to other functions. However, top management forced service integration, as underlined by the Service Innovation Director:

"[...] we work on the transversality of service as a value through business processes, integrating change into everyday life [...]."

Enhanced collaboration with customers and a deep customers analysis incited service integration: diminished market scepticism and improved Aura performances let the service function gain credibility. Integration efforts are not concluded yet:

"At a strategic level, Alpha does not intend to retreat in the development of the platform [...] we are experiencing an alignment of the platform with its competitors and a slow conversion of customers towards digital services [...] the effort we must make today for the healthy development of the project is to integrate Aura with the other solutions of the company" [Service Innovation Director-Alpha].
The role of top management was crucial in the assessment phase of Aura. However, internal conditions changed throughout the project: new directors arrived, an Aura department with new employees was created, digital services were offered and sold. A revision of the hierarchical and leadership structure became essential, shedding light on an additional tension:

\section{T6: Top-down vs Bottom-up leadership model}

At this point of Aura's fulfillment, the organizational layout of Alpha was still quite rigid and related to an inflexible mindset. The product-centric identity of the firm was present, as well as a hierarchical framework:

"The organizational management of the platform is led at a high level by a formalized change management procedure..." [Service Innovation Director Alpha].

The group could endure with the top-down approach to DS or converge toward a bottom-up model with strengthened responsibilities toward the lowest hierarchical levels.

Alpha's solution resided in a hybrid approach. Since its beginning, Aura was supervised by the top management. With time, employees struggling to modify routines and to catch the value of the DSS pushed the top direction toward a listening approach. A mix of top-down leadership and bottom-up initiatives was activated. The DSS was supported by a formalized change management approach, while commitment was stimulated. A series of bottom-up initiatives were provided:

"Different initiatives started [...] For example, we created an internal competition [...], because we wanted people to be stimulated and involved with Aura [...] everyone could share Aura implementation proposals...the best proposal won and was actually implemented" [Marketing Official Alpha].

Between hybrid initiatives, the biweekly meeting with managers and employees to check the Aura status. Directors and employees share progress, doubts and difficulties and collaborate to solve issues. Innoconsulting is responsible for moderating the meetings. Its constant presence along with the project significantly helps Alpha in overcoming DS barriers and improving the implementation of Aura.

\section{Discussions}

Existing literature on DS explores its intra- and interorganizational challenges in-depth, adopting fragmented approaches (Sjödin et al., 2019; Frank et al., 2019). Nevertheless, the reasons behind DS complexity for manufacturers are still unclear. This study approaches DS with an original perspective, adopting the paradox theory lens (Smith and Lewis, 2011) to explore DS tensions at the intraand inter-organizational levels.

The study provides a theoretical model which explains the origin of complexity in DSS as the result of combined intraand inter-organizational challenges and circumstances. The empirical analysis of Alpha highlights the emergence of six paradoxical tensions. Every tension is triggered by the collision between the firm's DS challenges and the arbitrary circumstances in which it operates. Starting from the conceptualization of the DS phenomenon and the empirical investigation of Alpha, an empirical framework figure is provided (Figure 3 ). 
Figure 3 Empirical framework

\begin{tabular}{|c|c|c|c|c|}
\hline \multicolumn{3}{|c|}{ INTRAORGANIZATONAL LEVE } & \multicolumn{2}{|c|}{ INTERORGANIZATIONAL LEVE } \\
\hline CHAШENGES & & GRCUMSTANCES & CHAШENGES & CIRCUMSTANCES \\
\hline \multicolumn{3}{|c|}{ (త) PROJECT DESIGN } & \multicolumn{2}{|c|}{ ๑ PROJECT DESIGN } \\
\hline $\begin{array}{l}\text { - Manage big data } \\
\text { - Build highly specialized knowledge and } \\
\text { capabilities for DS } \\
\text { - Oreate and protect competitive advantage }\end{array}$ & \multicolumn{2}{|c|}{$\begin{array}{l}\text { - Scarse resources } \\
\text { - Lack of capabilities and competences }\end{array}$} & $\begin{array}{l}\text { - Recognize financial and technological readiness } \\
\text { of customers for digital services } \\
\text { - Co-create value with customers } \\
\text { - Respond to market dynamism } \\
\text { - Oreate multi-actor partnerships underpinned by } \\
\text { trust } \\
\text { - Improve strategic position in the value chain } \\
\text { - Exploit provider-customer relationships to } \\
\text { maximize DS benefits }\end{array}$ & $\begin{array}{l}\text { - Limited collaboration with customers } \\
\text { - Technologically underdeveloped environment } \\
\text { - Oustomers' scepticism on digital tools } \\
\text { - High competition } \\
\text { - Entrusted collaboration with supplier }\end{array}$ \\
\hline \multicolumn{3}{|c|}{ (J) PROJECT IMPLEMENTATION } & \multicolumn{2}{|c|}{ (1) PROJECT IMPLEMENTATION } \\
\hline $\begin{array}{l}\text { - Split and share resources between functions } \\
\text { - Optimize the change management process } \\
\text { - Effective acceptance of the service } \\
\text { empowerment } \\
\text { - Manage different market needs } \\
\text { - Build and spread new knowledge across the } \\
\text { organization }\end{array}$ & \multicolumn{2}{|c|}{$\begin{array}{l}\text { - Oultural resistances } \\
\text { - Information asymmetries } \\
\text { - Scarse resources } \\
\text { - Lack of capabilities and competences }\end{array}$} & $\begin{array}{l}\text { - Manage network relationships for the DSS } \\
\text { - Co-create value with different customers } \\
\text { - Recognize financial and technological readiness } \\
\text { of local customers }\end{array}$ & $\begin{array}{l}\text { - Limited collaboration with customers } \\
\text { - Oustomers' scepticism on digital tools }\end{array}$ \\
\hline \multicolumn{3}{|c|}{ (7) PROJECT ASSESSMENT } & \multicolumn{2}{|c|}{ () PRONECT ASSESSMENT } \\
\hline $\begin{array}{l}\text { - Integrate product and service orientation } \\
\text { - Establish innovative structures and cultural } \\
\text { openness } \\
\text { - Optimize the change management process } \\
\text { - Align the value system to the DSS } \\
\text { - Lead the cultural change process } \\
\text { - Adapt the organizational structure to a flexible } \\
\text { DS mindset }\end{array}$ & \multicolumn{2}{|c|}{$\begin{array}{l}\text { - Oultural resistances } \\
\text { - Information asymmetries } \\
\text { - Product-centric identity } \\
\text { - Herarchical structure }\end{array}$} & $\begin{array}{l}\text { - Co-create value with customers at every step } \\
\text { of the sales process }\end{array}$ & - Oustomers' scepticism on digital tools \\
\hline \multirow{2}{*}{\multicolumn{2}{|c|}{ 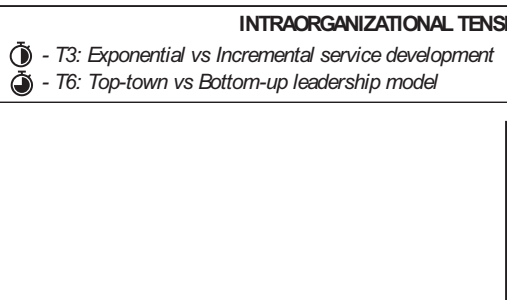 }} & AONS & \multicolumn{2}{|c|}{$\begin{array}{l}\text { INTERORGANIZATIONAL TIENSIONS } \\
(-) \text { - T1: Pull vs Push technology-based innovation }\end{array}$} \\
\hline & & \multicolumn{2}{|c|}{$\begin{array}{l}\text { INTRAINTERORGANIZATIONAL TENSIONS } \\
\text { Ð - T2: Firm-driven vs Supply chain-driven technological know-how } \\
\text { acquisition } \\
\text { ( - T4: Diversification vs Standardization of the international service } \\
\text { offering } \\
Ð \text { - T5: Integrated vs Disintegrated service function }\end{array}$} & \\
\hline
\end{tabular}

The empirical framework depicts the tensions experienced by Alpha, which, in turn, validate concepts and structure of the theoretical framework. Compared to it, the empirical framework includes an additional dimension to space: time. Every tension comes from a specific temporal phase and organizational level: $\mathrm{T} 1$ and $\mathrm{T} 2$ emerged in the design phase; $\mathrm{T} 3$ and $\mathrm{T} 4$ belong to the implementation phase; $\mathrm{T} 5$ and $\mathrm{T} 6$ to the assessment phase. $\mathrm{T} 1$ is the only tension that originated purely at the inter-organizational level. Conversely, T3 and T6 arose as intra-organizational. T2, T4 and $\mathrm{T} 5$ are simultaneously intra- and inter-organizational in nature, as challenges and circumstances that determined them can be found at both levels.

Because of the time- and space-related focus of the framework, it is possible to observe elements of complexity in the DS path of Alpha. Findings reveal how one element of complexity resides in the multilevel component of tensions and in the presence of "hybrid" tensions. DS complexity arises from the combination of multiple, interrelated elements. Not only DSS is embedded in a multi-level perspective, which involves the network, organizational and micro-foundational levels (Struyf et al., 2021). Also, at every level paradoxes arise from the strategy, with implications that mix and switch between them.

Another element of complexity is the multiplicity of tensions appearing across time. In Alpha, tensions originating at one level in one phase are intertwined with other levels and phases.
Firms must deal with DS while preserving their business-asusual; the significant and increasing number of DS challenges adds to the firm's daily hurdles. Moreover, results show how inefficient choices in the first phases of the DSS enhance the risk of tensions accumulation over time: an action can be effective to solve one tension while it triggers inefficiency for others. Being DS a journey, time is crucial in leading the organizational change (Mento et al., 2002). If not properly managed, the risk of accumulating tensions increases.

The case study analysis confirms the relevance of the context for the success of DS; coordination is required among strategy, environment and organization (Feng et al., 2021). In addition, it underlines the importance of monitoring organizational changes caused by DS as a univocal process. In Alpha, intertwined tensions result from the lack of a holistic overview of all tensions. Missing the big picture on DS tensions leads to the development of individual solutions, effective for one tension but ineffective for others. This is what happened in T1, where the reduced customer orientation implied difficulties in conveying value to the market (T4), which in its turn led to internal resistances due to uncertain Aura performances (T5). Similarly, the acquisition of external know-how solved T2; however, it reflected resistances and scarce collaboration of employees, especially in the sales function, while solving T3. Imposing the service growth worked as a solution to T3, but it created internal frictions still visible when T6 emerged. 
Summarizing the path of Alpha, relevant considerations can be drawn in terms of actions to limit DS complexity. Alpha adopted an iterative approach with the continuous revaluation of choices, which demonstrated effectiveness. Each implemented action reduced part of the complexity; interventions during the implementation and assessment phases became key to dissolving issues accumulated from the project start. The service integration efforts and the hybrid leadership approach in the assessment phase solved organizational frictions that appeared in the design and implementation phases. Recent attempts to be more customer-oriented and less dependent on Innoconsulting solved previous inter-organizational issues. Research findings suggest the relevance of an iterative, continuous improvement approach to destroy DS complexity, together with the ability to establish a detecting system to promptly recognize new tensions. To facilitate manufacturers in achieving an overarching view on the DS journey, the empirical framework can be a valid tool. Creating and integrating an empirical framework with tensions encountered throughout the DSS empowers the awareness of firms on the DS process.

The research also facilitates the observation of elements of convergence and divergence between servitization and DS paradoxes. In general terms, our findings suggest that DS is more complex than servitization; its digital dimension hinders the entire process because of the required skills not only at the network level (Matthyssens, 2019; Kamalaldin et al., 2020) but even at the organizational one. In relation to service integration, T5 can emerge in both servitization and DS (Lenka et al., 2018; Kohtamäki et al., 2020), as the tension is not directly linked to digital aspects. Conversely, the tension on the leadership model calls for further elucidation (Kowalkowski et al., 2017; Kim and Toya, 2019). This study underlines how T6 becomes more complex in DSS. The digital dimension requires technological infrastructures and the service delivery system to be understood, internalized and diffused within and outside the firm. The relevance of the leadership model in guiding servitizing projects is confirmed for both strategies (Ahamed et al., 2013). However, the inefficacy of an autocratic and autonomous leadership for DS is questioned (Kim and Toya, 2019). Findings reveal how a DSS needs a balance between autonomous and charismatic leadership models and how decisions involving service empowerment should be imposed before being accepted.

\section{Conclusions}

Firms involved in DSS face complexity at the intra- and interorganizational level, which can take the shape of paradoxical tensions (Vendrell-Herreo et al., 2017; Harini and Thomas, 2020). The inability to manage such complexity can undermine the success of the strategy. This study aims at pinpointing the origin of complexity in DSS to feel a gap in the literature. It answers the call of Kohtamäki et al. (2020) for further research on the topic while providing managerial implications. By answering the two RQs, this research advances knowledge on DSS through the combination of servitization literature with the paradox theory lens (Bustinza et al., 2018; Smith and Lewis, 2011).

RQ1 investigates how the emergence of intra- and interorganizational tensions generate complexity along a DSS. This research confirms the high complexity of DSS (Tronvoll et al., 2020). Moreover, it disentangles DS complexity into tensions at the intra- and inter-organizational levels. Six tensions result from the study: Pull vs Push technology-based innovation, Firmdriven vs Supply-chain driven technological know-how acquisition, Exponential vs Incremental service development, Diversification vs Standardization of the international service offering, Integrated vs Disintegrated service function, Top-down vs Bottom-up leadership model. Our findings emphasize how the multiplicity and interrelatedness of such tensions intricate the DS journey of manufacturers. Complexity reveals even enhanced by the digital component of the DSS, calling for specific organizational and network capabilities. Time becomes a determinant variable in the DS process: tensions accumulation across the DS phases seriously undermines the strategy efficacy.

RQ2 looks at where and when manufacturers can intervene to dissolve DS complexity. The interrelated analysis of tensions across space and time unveils DS criticalities (Paiola and Gebauer, 2020; Coreynen et al., 2017). Specific actions emerge, which can support firms in unraveling DS complexity. In the DSS design, context analysis, networking exploitation and focus on customer needs and expectations are required. During the DSS implementation, attention should be devoted to the iterative adjustment of organizational issues, with an autonomous leadership style. In the assessment phase, external knowledge dependence and leadership rigidity are to be reduced.

\subsection{Managerial implications}

By disentangling where and when complexity originates in DSS, this research provides insights and practical solutions for managers investing in this path. Suggestions on how to approach a DSS appear for each phase of the DS journey.

In the DSS design, monitoring activity of the surrounding context reveals vital. Managing purposeful network interactions is functional to identify potential DS partners and detect the market's aptitude toward digital services. The type of technology to link to the DSS should be defined at this stage. A push technology-based approach is not mandatory, especially for SMEs with limited access to resources. A pull approach, better suiting customer infrastructures, can be more appropriate. However, it should go hand in hand with the early integration of human resources, development of specific skills and cultural change management. Managers should consider the best DS journey given the organizational circumstances, as well as the best balance between the service and the digital prevalence in the strategy (Ciasullo et al., 2021).

At the implementation stage, two dimensions will need a particular focus: the customer perspective and organizational issues. An adaptive approach to the market is required to guarantee the dissemination of digital service value. At the same time, the continuous revaluation and assessment of organizational circumstances, such as resistances, cultural obstacles or the leadership model, will guarantee effective DS development. Between the organizational capabilities required in a DSS, there is the ability to iterate within the process and make continuous adjustments, to make nonexclusive choices in front of paradoxes (Kohtamäki et al., 2020) and to keep problems-detection systems active 
throughout the process. In this sense, the proposed empirical framework can work as a monitoring tool of DSS complexity. Managers can fill in the framework skeleton with challenges and circumstances they meet along with the DSS. This helps identify DS tensions and their origin and design solutions, which are functional for all the encountered tensions. The empirical framework provides a wider perspective on the strategy and avoids unilateral, silo-thinking (Struyf et al., 2021). A decisive and autonomous leadership style is suggested during the implementation phase.

In the assessment, the leadership model should experience a twist. A hybrid approach, combining top-down directives and bottom-up initiatives can be integrated. It helps reduce internal resistance and facilitates cultural openness toward digital services. Moreover, in the case of collaboration with external partners, it is crucial to internalize capabilities coming from the relationship. Managers could strengthen the internal knowhow at this stage to better defend the competitive advantage in the future. However, the preservation of key relationships is still consistent to face market dynamism and improve knowledge acquisition (Runfola et al., 2021).

\subsection{Limitations and future research directions}

This research is not without limitations. First, the longitudinal, in-depth single case study methodology restricts the area of investigation to a firm operating in one sector. Even if this allowed a detailed configuration of DSS complexity, future research could benefit from comparative case studies within multiple firms operating in different industrial branches. It could enrich knowledge on DS complexity and provide additional perspectives on the phenomenon. Moreover, quantitative studies can help test the framework for DS complexity, validate results and facilitate their generalizability.

Second, the influence of the external context can impact the strategic complexity: customers could not be ready to buy digital services and providers could not be collaborative on innovation dynamics (Vaittinen and Martinsuo, 2019; Vendrell-Herreo et al., 2017). This aspect needs further exploration, which was not possible to achieve with the available data. Future research could address the objective of disentangling the role of external actors in the success of DSS. Interestingly, it could involve the investigation of customers' readiness for digital services, supplierbuyer relationships in DS or the impact of policies and institutional networks in the success of DSS.

\section{Note}

1 The name of the case study firm, as well as the name of its project and the name of the official partner, has been anonymized to ensure confidentiality.

\section{References}

Ahamed, Z., Kamoshida, A. and Inohara, T. (2013), "Organizational factors to the effectiveness of implementing servitization strategy", fournal of Service Science and Management, Vol. 6, No. 2, pp. 177-185.
Altmann, P. and Linder, M. (2019), "Managing emerging (Mis)Alignments in data-driven Servitization", ResearchTechnology Management, Vol. 62 No. 4, pp. 37-45.

Ashforth, B.E., Rogers, K.M., Pratt, M.G. and Pradies, C. (2014), "Ambivalence in organizations: a multilevel approach", Organization Science, Vol. 25, No. 5, pp. 1453-1478.

Baines, T. and Lightfoot, H.W. (2013), "Servitization of the manufacturing firm: exploring the operations practices and technologies that deliver advanced services", International Fournal of Operations \& Production Management, Vol. 34, No. 1, pp. 2-35.

Burton, J., Story, V., Zolkiewski, J., Raddats, C., Baines, T.S. and Medway, D. (2016), "Identifying tensions in the servitized value chain", Research-Technology Management, Vol. 59, No. 5, pp. 38-47.

Bustinza, O.F., Gomes, E., Vendrell-Herrero, F. and Tarba, S.Y. (2018), "An organizational change framework for digital servitization: Evidence from the Veneto region", Strategic Change, Vol. 27, No. 2, pp. 111-119.

Ciasullo, M.V., Polese, F., Montera, R. and Carrubbo, L. (2021), "A digital servitization framework for viable manufacturing companies", fournal of Business E Industrial Marketing, Vol. 36, No. 13, pp. 142-160.

Colm, L., Ordanini, A. and Bornemann, T. (2020), "Dynamic Governance Matching in Solution Development", fournal of Marketing, Vol. 84, No. 1, pp. 105-124.

Coreynen, W., Matthyssens, P. and Van Bockhaven, W. (2017), "Boosting servitization through digitization: Pathways and dynamic resource configurations for manufacturers", Industrial Marketing Management, Vol. 60, pp. 42-53.

Denzin, N.K. (1978), The Research Act: A Theoretical Introduction to Sociological Methods, Second Edition, McGrawHill, New York, NY.

Dubois, A. and Gadde, L.E. (2002), "Systematic combining: an abductive approach to case research", fournal of Business Research, Vol. 55, No. 7, pp. 553-560.

Feng, C., Jiang, L., Ma, R. and Bai, C. (2021), "Servitization strategy, manufacturing organizations and firm performance: a theoretical framework", Fournal of Business E Industrial Marketing, Vol. 36, No. 10, pp. 1909-1928.

Frank, A.G., Mendes, G.H.S., Ayala, N.F. and Ghezzi, A. (2019), "Servitization and Industry 4.0 convergence in the digital transformation of product firms: a business model innovation perspective", Technological Forecasting and Social Change, Vol. 141, pp. 341-351.

Gebauer, H., Fleisch, E. and Friedli, T. (2005), “Overcoming the service paradox in manufacturing companies", European Management fournal, Vol. 23, pp. 14-26.

Grandinetti, R., Ciasullo, M.V., Paiola, M. and Schiavone, F. (2020), "Fourth industrial revolution, digital servitization and relationship quality in Italian BtoB manufacturing firms. An exploratory study", The TQM fournal, Vol. 32, No. 4, pp. 647-671.

Gummesson, E. (2003), “All research is interpretive!”, fournal of Business \& Industrial Marketing, Vol. 18, No. 6/7, pp. 482-492.

Halinen, A. and Törnroos, J.A. (2005), "Using case methods in the study of contemporary business networks", Fournal of Business Research, Vol. 58, No. 9, pp. 1285-1297. 
Harini, K.N. and Thomas, M.T. (2020), "Understanding interorganizational network evolution", fournal of Business E Industrial Marketing, Vol ahead-of-print, No. ahead-ofprint.

Hasselblatt, M., Huikkola, T., Kohtamäki, M. and Nickell, D. (2018), "Modeling manufacturer's capabilities for the internet of things", Fournal of Business E Industrial Marketing, Vol. 33, No. 6, pp. 822-836.

Heidrick and Struggles (2015), "The CEO report: Embracing the paradoxes of leadership and the power of doubt", available at: www.heidrick.com/knowledge-center/Publication/The-CEOReport (accessed 22 September 2020).

Hunter, M.G. (2012), "Creating Qualitative Interview Protocols", International fournal of Sociotechnology and Knowledge Development, Vol. 4, No. 3, pp. 1-16.

Jonsen, K. and Jehn, K.A. (2009), "Using triangulation to validate themes in qualitative studies", Qualitative Research in Organizations and Management, Vol. 4, No. 2, pp. 123-150.

Kamalaldin, A., Linde, L., Sjödin, D. and Parida, V. (2020), "Transforming provider-customer relationships in digital servitization: a relational view on digitalization", Industrial Marketing Management, Vol. 89, pp. 306-325.

Kim, S. and Toya, K. (2019), "Leadership style required for the transition to servitization in Japan", fournal of Manufacturing Technology Management, Vol. 30, No. 2, pp. 335-352.

Kohtamäki, M., Einola, S. and Rabetino, R. (2020), "Exploring servitization through the paradox lens: Coping practices in servitization", International fournal of Production Economics, Vol. 226, pp. 1-15.

Kowalkowski, C., Gebauer, H., Kamp, B. and Parry, G. (2017), "Servitization and deservitization. Overview, concepts, and definitions", Industrial Marketing Management, Vol. 60, pp. 4-10.

Lenka, S., Parida, V., Sjödin, D.R. and Wincent, J. (2018), "Towards a multi-level servitization framework: conceptualizing ambivalence in manufacturing firms", International fournal of Operations \& Production Management, Vol. 38, No. 3, pp. 810-827.

Lindgreen, A., Di Benedetto, C.A. and Beverland, M.B. (2020), "Editorial: how to write up case-study methodology sections", Industrial Marketing Management, Vol. 96, pp. A7A10.

Martìn-Peña, M.L., Sánchez-López, J.M. and Díaz-Garrido, E. (2019), "Servitization and digitalization in manufacturing: the influence on firm performance", fournal of Business \& Industrial Marketing, Vol. 35, No. 3, pp. 564-574.

Matthyssens, P. (2019), "Reconceptualizing value innovation for industry 4.0 and the industrial internet of things", fournal of Business \& Industrial Marketing, Vol. 34, No. 6, pp. 1203-1209.

Matthyssens, P. and Vandenbempt, K. (2008), "Moving from basic offerings to value-added solutions: strategies, barriers and alignment", Industrial Marketing Management, Vol. 37, pp. 316-328.

Mento, A.J., Jones, R.M. and Dirndorfer, W. (2002), “A change management process: grounded in both theory and practice", Fournal of Change Management, Vol. 3, No. 1, pp. 45-59.

Meyer, C.B. (2001), “A case in case study methodology”, Field Methods, Vol. 13, No. 4, pp. 329-352.
Morgan, B. (2019), “100 Stats on Digital Transformation and Customer Experience", Forbes, Dec 16, 2019, available at: www.forbes.com/sites/blakemorgan/2019/12/16/100-statson-digital-transformation-and-customer-experience/?sh= a 7 bffa23bf3e (accessed 13 January 2021).

Paiola, M. and Gebauer, H. (2020), "Internet of Things technologies, digital servitization and business model innovation in BtoB manufacturing firms", Industrial Marketing Management, Vol. 89, pp. 245-264.

Putnam, L.L., Fairhurst, G.T. and Banghart, S. (2016), "Contradictions, dialectics, and paradoxes in organizations: a constitutive approach", The Academy of Management Annals, Vol. 10, No. 1, pp. 65-171.

Reim, W., Sjödin, D.R. and Parida, V. (2018), "Mitigating adverse customer behaviour for product-service system provision: An agency theory perspective", Industrial Marketing Management, Vol. 74, pp. 150-161.

Ruiz-Alba, J.L., Soares, A., Rodríguez-Molina, M.A. and Frías-Jamilena, D.M. (2019), "Servitization strategies from customers' perspective: the moderating role of co-creation", Fournal of Business E Industrial Marketing, Vol. 34, No. 3, pp. 628-642.

Runfola, A., Milanesi, M. and Guercini, S. (2021), "Rethinking interaction in social distancing times: implications for business-to-business companies", fournal of Business $\mathcal{E}$ Industrial Marketing, Vol. 36, No. 13, pp. 105-115.

Salo, J., Tan, T.M. and Makkonen, H. (2021), "Digitalization of the buyer-seller relationship in the steel industry", fournal of Business \& Industrial Marketing, Vol. 36, No. 7, pp. 1229-1245.

Sandelowski, M. (1999), "Focus on qualitative methods. Time and qualitative research", Research in Nursing \& Health, Vol. 22, pp. 79-87.

Sjödin, D.R., Parida, V. and Kohtamäki, M. (2019), "Relational governance strategies for advanced service provision: multiple paths to superior financial performance in servitization", fournal of Business Research, Vol. 101, pp. 906-915.

Sjödin, D.R., Parida, V., Kohtamäki, M. and Wincent, J. (2020), "An agile co-creation process for digital servitization: a micro-service innovation approach", Fournal of Business Research, Vol. 112, pp. 478-491.

Smith, W.K. and Lewis, M.W. (2011), "Toward a theory of paradox: a dynamic equilibrium model of organizing", Academy of management Review, Vol. 36, No. 2, pp. 381-403.

Struyf, B., Galvani, S., Matthyssens, P. and Bocconcelli, R. (2021), "Toward a multilevel perspective on digital servitization", International fournal of Operations $\mathcal{E}$ Production Management, Vol. 41 No. 5, pp. 668-693.

Thirsk, L.M and Clark, A.M. (2017), "Using qualitative research for complex interventions: the contributions of Hermeneutics", International Fournal of Qualitative Methods, Vol. 16, pp. 1-10.

Tronvoll, B., Sklyar, A., Sörhammar, D. and Kowalkowski, C. (2020), "Transformational shifts through digital servitization", Industrial Marketing Management, Vol. 89, pp. 293-305.

Vaittinen, E. and Martinsuo, M. (2019), "Industrial customers' organizational readiness for new advanced 
services", fournal of Manufacturing Technology Management, Vol. 30, No. 7, pp. 1073-1096.

Vargo, S.L. and Lusch, R.F. (2011), "It's all B2B...and beyond: toward a systems perspective of the market", Industrial Marketing Management, Vol. 40, pp. 181-187.

Vendrell-Herreo, F., Bustinza, O.F., Parry, G. and Georgantzis, N. (2017), "Servitization, digitization and supply chain interdependency", Industrial Marketing Management, Vol. 60, pp. 69-81.

Wagstaff, S., Burton, J. and Zolkiewski, J. (2021), "Tensions and territoriality: the dark side of servitization", fournal of Business E Industrial Marketing, Vol. 36 No. 10, pp. 1755-1766.
Waldman, D.A., Putnam, L.L., Miron-Spektor, E. and Siegel, D. (2019), "The role of paradox theory in decision making and management research", Organizational Behavior and Human Decision Processes, Vol. 155, pp. 1-6.

Wellener, P., Umbenhauer, B., Dollar, B., Zale, J. and Ashton, H. (2020), "Navigating distruption. Five trends influencing tomorrow's manufacturing industry", Deloitte Insights, available at: www2.deloitte.com/us/en/insights/ industry/manufacturing/future-trends-in-manufacturing.html (accessed 13 January 2021).

Yin, R.K. (2009), Case Study Research - Design and Methods, 4th ed., SAGE Publications, Thousand Oaks, CA. 


\section{Appendix}

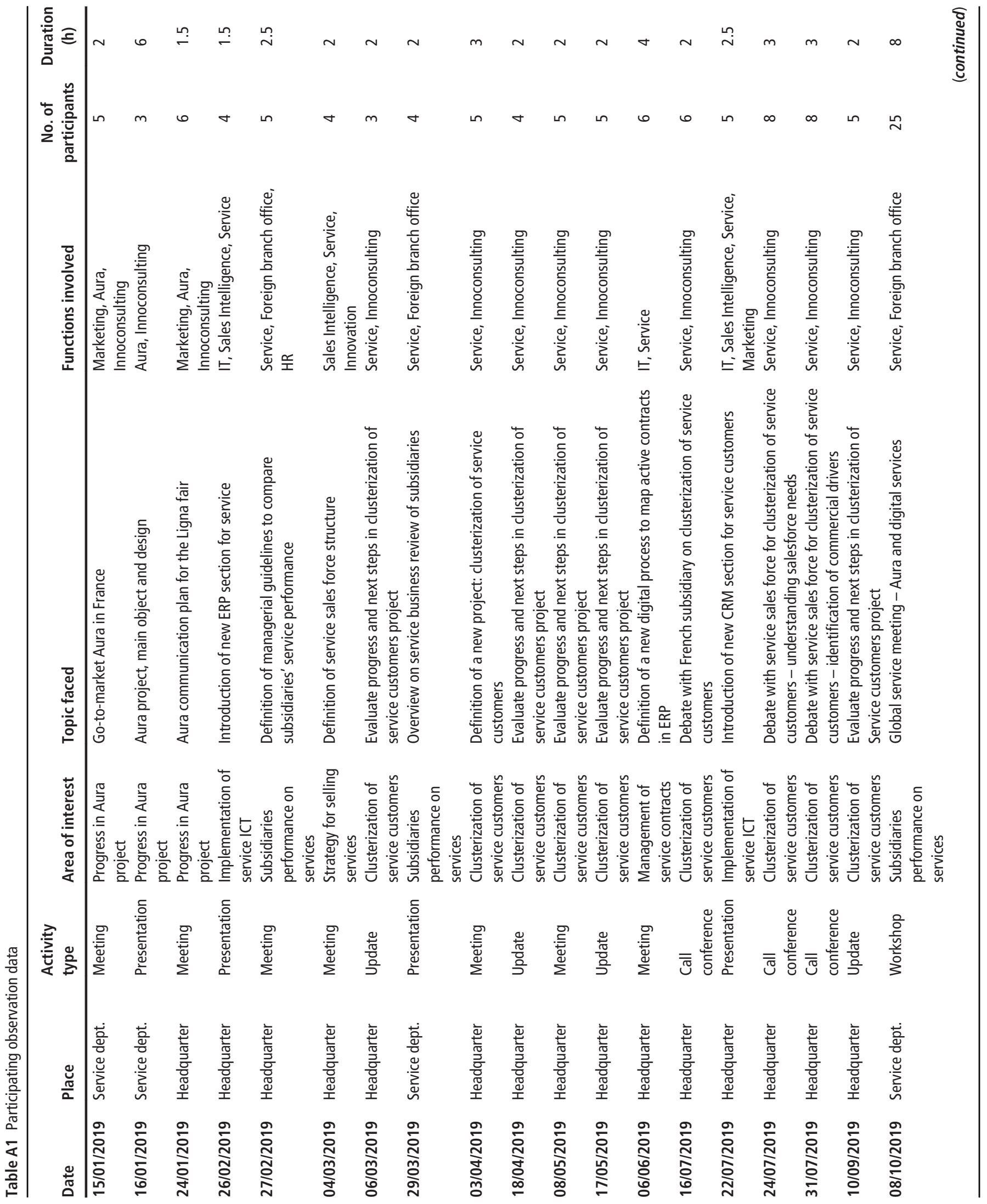




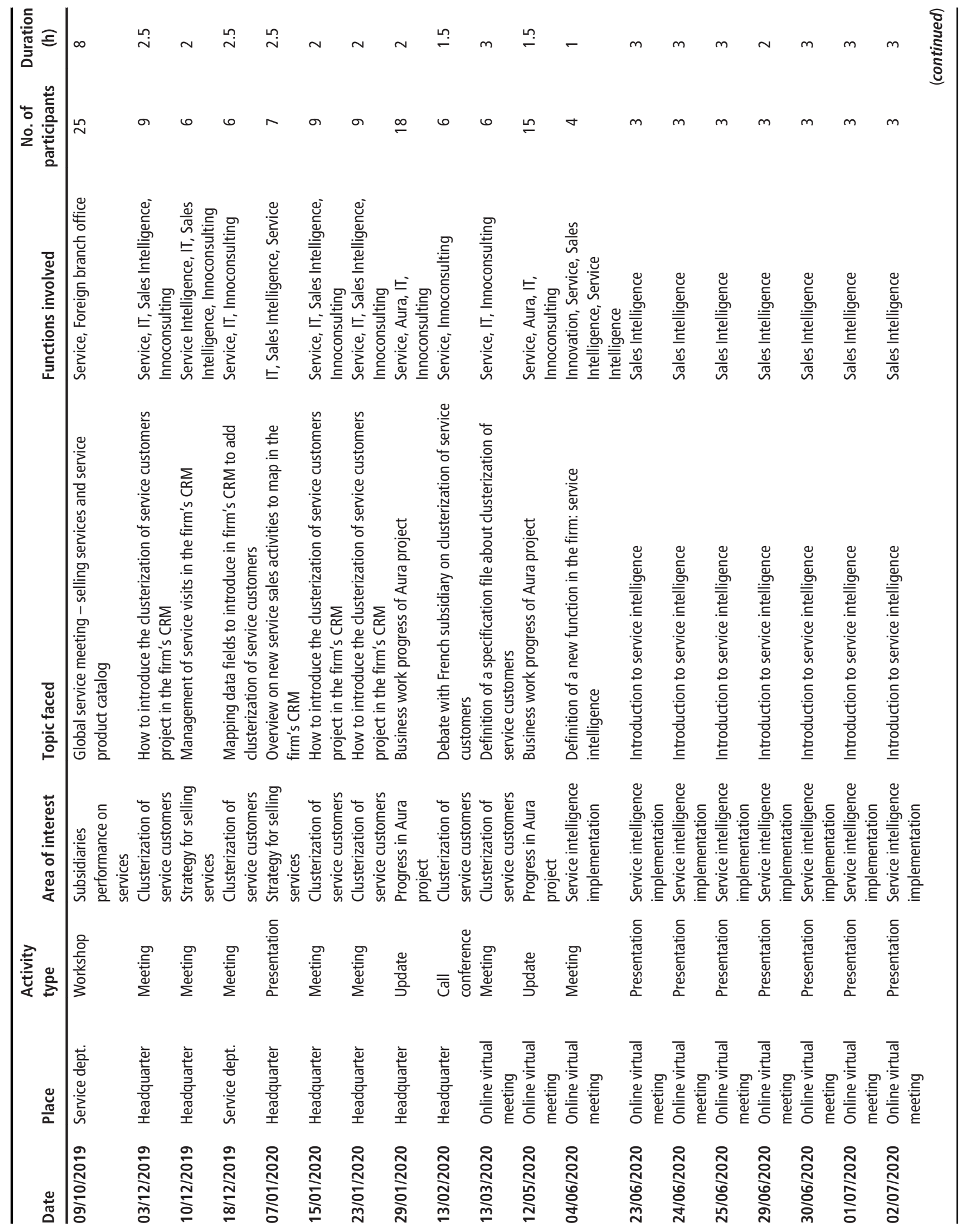




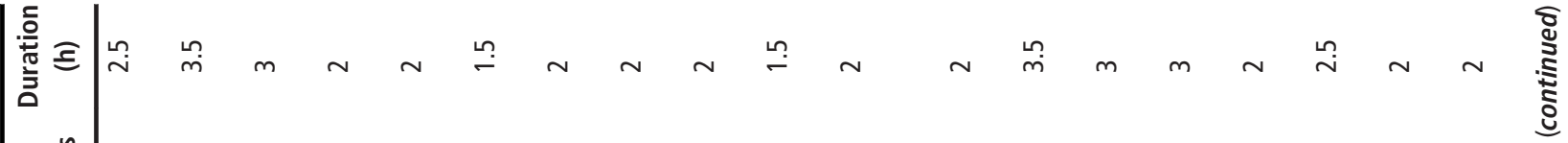

항.

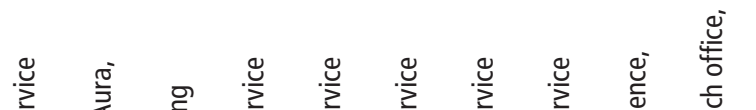

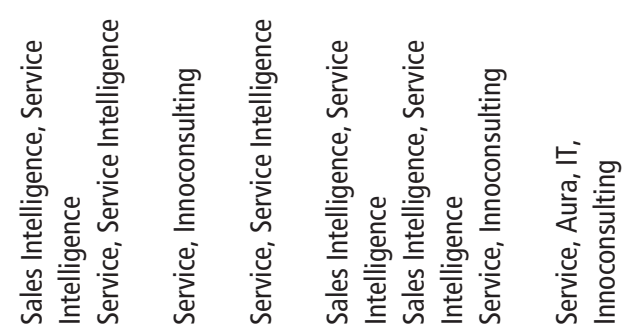

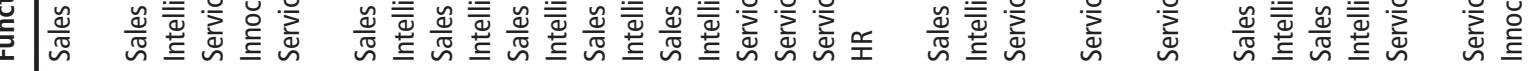
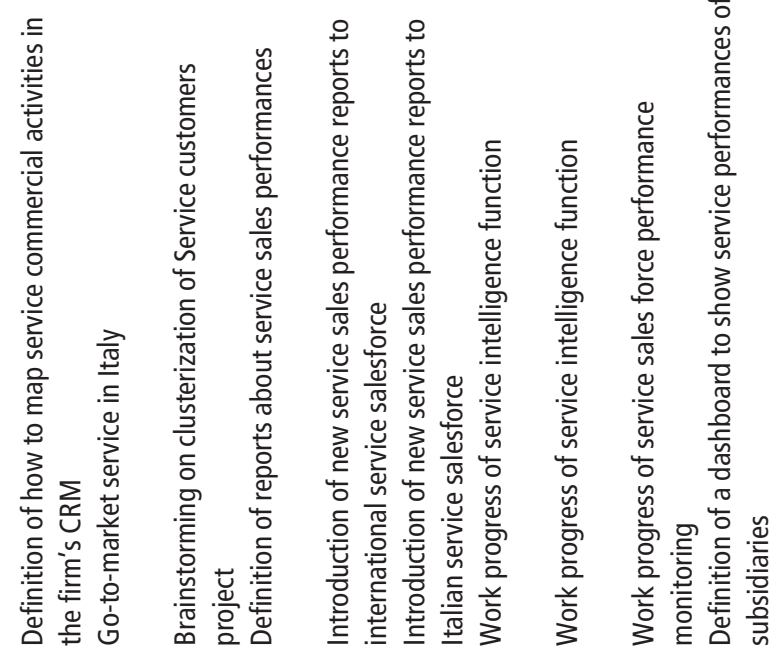

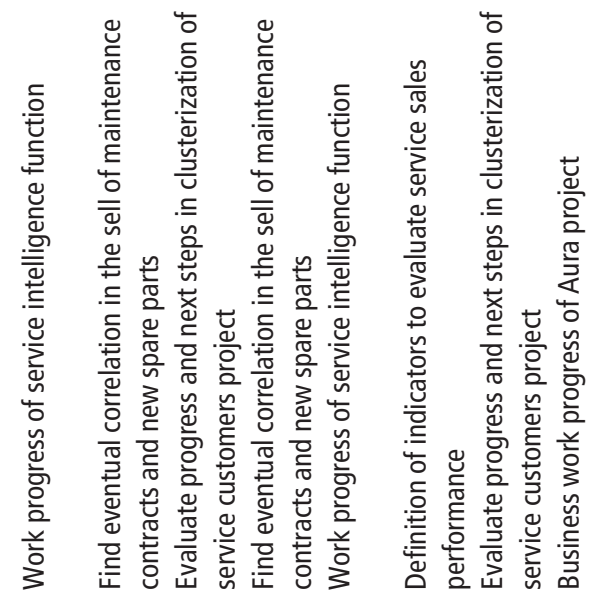

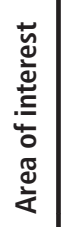

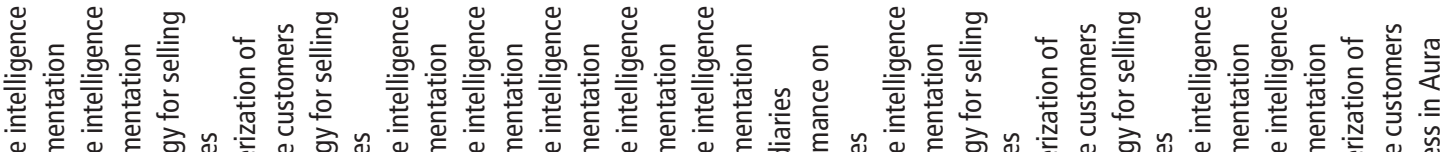

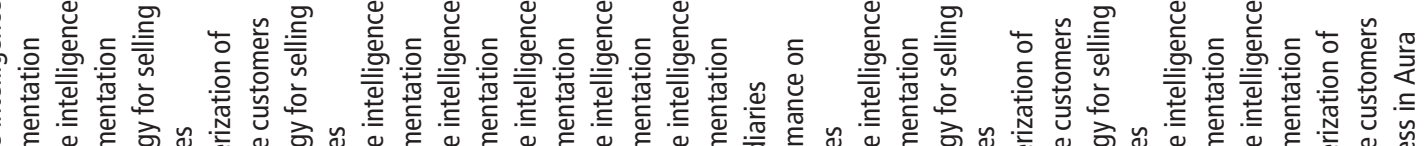

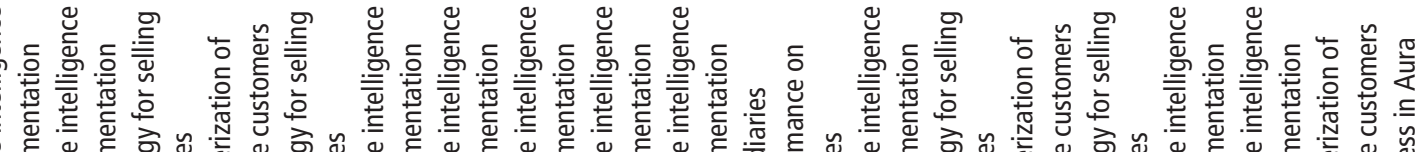

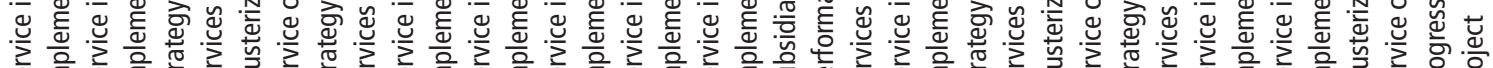

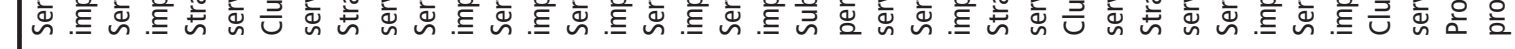

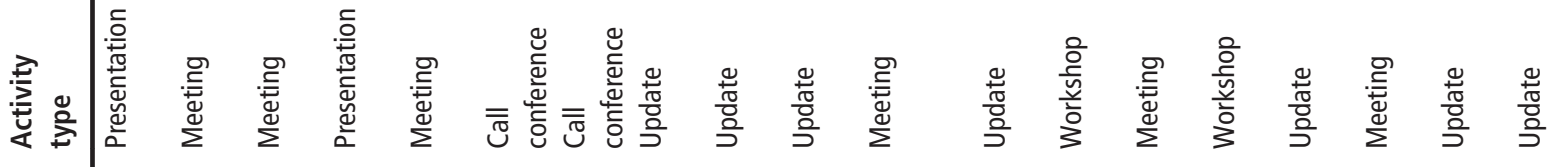

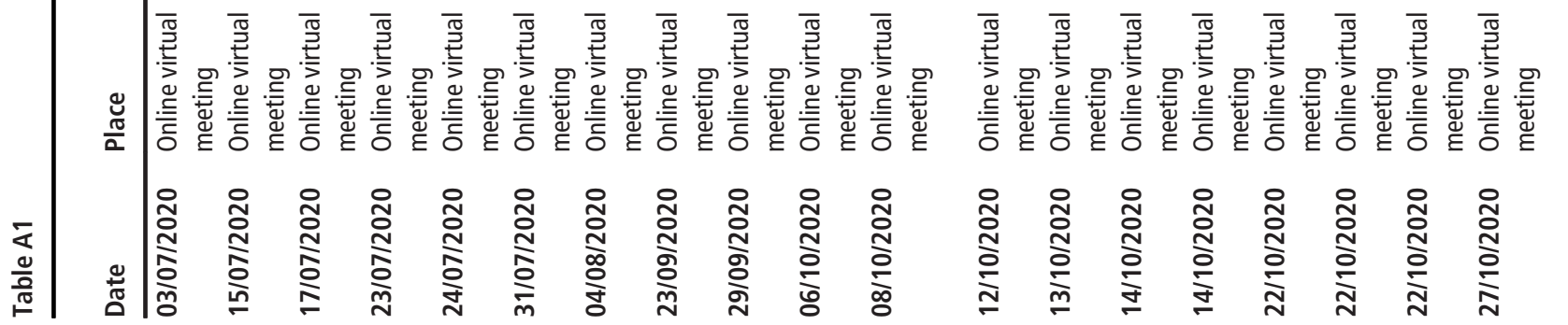




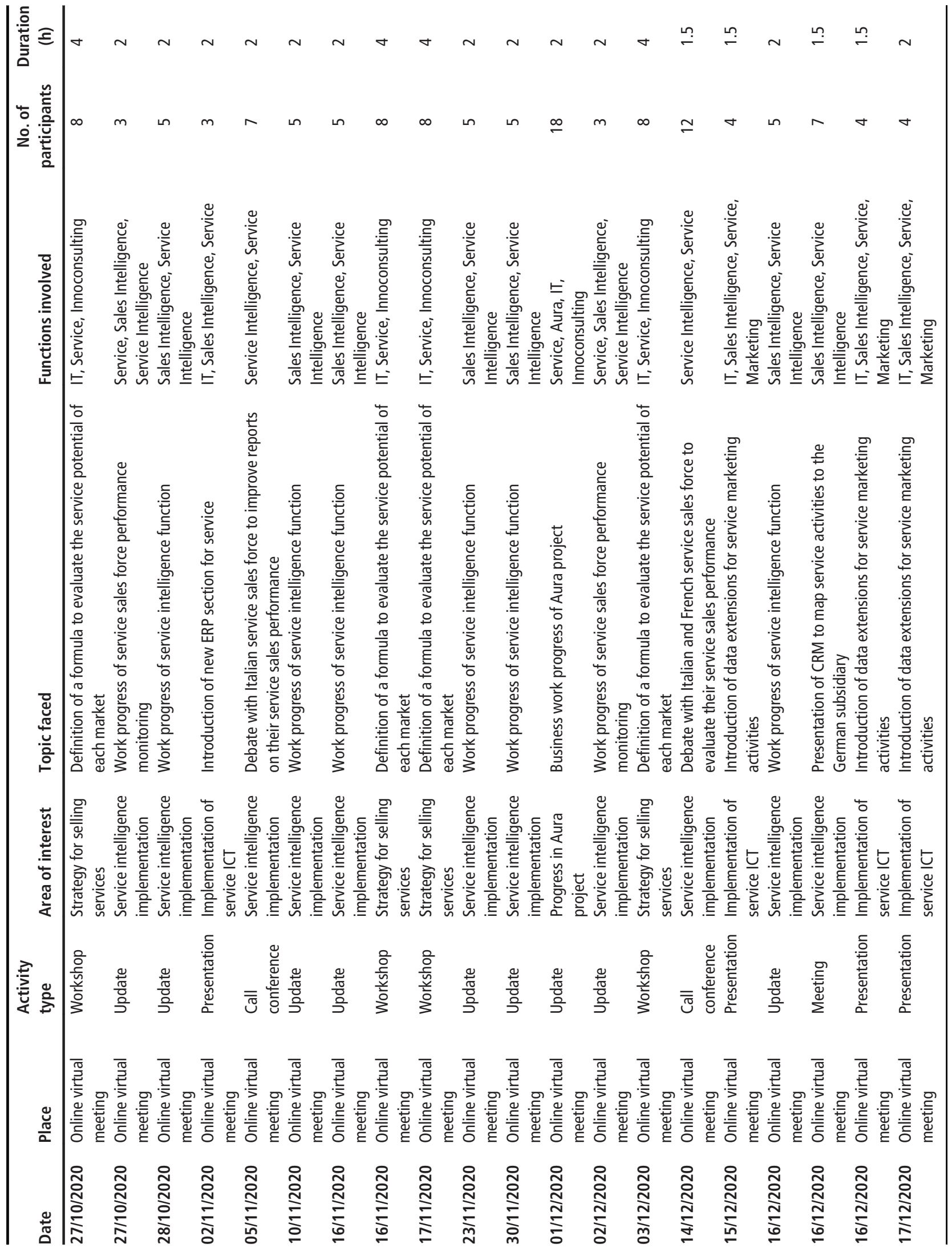


Table A2 Interview protocol.

\begin{tabular}{|c|c|c|}
\hline Section & Topic & Questions \\
\hline 1 & Identification of the respondent & $\begin{array}{l}\text { - What is your position inside the company today? } \\
\text { - What are the main responsibilities connected to your working position? } \\
\text { - Does your current working position include transversality between organizational functions? } \\
\text { - If yes, which ones? } \\
\text { - Does your current working position involve direct contact with external actors? } \\
\text { - Is this your first role in the company? } \\
\text { - If not, which role(s) did you perform previously? } \\
\text { - How long have you been working in the company? } \\
\text { - Do you have working experience in other firms? } \\
\text { - If yes, which ones? }\end{array}$ \\
\hline 2 & Description of the DSS & $\begin{array}{l}\text { - Can you describe the DSS of the firm? } \\
\text { - What have been the main phases or stages, experienced along with the DSS? } \\
\text { - In your opinion, what are the critical events characterizing the DSS? } \\
\text { - In temporal terms, when did the firm start considering the option of a DSS? } \\
\text { - When did the official implementation of the DSS start? } \\
\text { - What are the main events that followed the official start? } \\
\text { - Was the firm involved in service strategies before officially investing in the DSS? } \\
\text { - If yes, how? } \\
\text { - How would you define the service orientation of the firm before the DSS? } \\
\text { - Would you define it differently today, after the initiation of the DSS? } \\
\text { - Which stage of the DSS process do you think the firm is experiencing today? } \\
\text { - What are your expectations about the future developments of the DSS? }\end{array}$ \\
\hline 3 & Implications of the DSS and solutions & $\begin{array}{l}\text { - Could you identify the conditions that triggered the idea of the DSS? } \\
\text { - While evaluating the DSS idea, what were the main concerns and perceived barriers? } \\
\text { - What were, instead, the facilitators in choosing to invest? } \\
\text { - Inter the initial decision to invest, what were the main changes? } \\
\text { - What where the main organizational criticalities? } \\
\text { - Did some resistances emerge? } \\
\text { - If yes, of what kind? How have they been managed? } \\
\text { - Which functions were mostly involved in the DSS at this stage? } \\
\text { - What did you perceive as the main advantage of the DSS at this stage? } \\
\text { - How was the leadership involved in this stage? } \\
\text { - Did you need the support of external actors? } \\
\text { - If yes, what actors? } \\
\text { - For what purposes? } \\
\text { - Did some existing relations with external actors modify because of the DSS? } \\
\text { - If yes, which ones and why? } \\
\text { - What were the main difficulties in the relationship with the external actors at this stage, if any? } \\
\text { - How have they eventually been managed? } \\
\text { - During the official launch of the DSS, what were the main changes? } \\
\text { - Internally, were some changes in the organizational structure required? } \\
\text { - If yes, of what type and why? } \\
\text { - What were the main barriers that you perceived during this stage of the DSS? } \\
\text { - How have they eventually been managed? } \\
\text { - What advantages of the DSS did you perceive in this stage, if any? } \\
\text { - What was the reaction of employees? } \\
\text { - How was the leadership involved in this stage? } \\
\text { - Toward the external actors, what happened? } \\
\text { - Were new actors involved at this stage? which ones and why? } \\
\text { - What barriers did you perceive in the relation with external actors? }\end{array}$ \\
\hline
\end{tabular}


Table A2

\begin{tabular}{cc}
\hline Section Topic & Questions \\
- If any, which ones and in relation to which actor? How have they eventually been managed? & - How did customers react to the introduction of digital services? \\
- What are the main activities led today in relation to the DSS? \\
- Do you feel there are still internal criticalities related to the DSS? \\
- If yes, which ones? \\
- What strategies of the firm do you think we're the most effective to solve previous criticalities if any? \\
- What is today the response of employees to the DSS? \\
- What are the perceived advantages acquired from the DSS today? \\
- How is the leadership involved in the DSS today? \\
- How is now the responsibility of the external actors to the DSS? \\
- How do customers react to the DSS today? \\
- How is the relationship with suppliers managed? \\
- What is the institutional and public response of the market to the DSS?
\end{tabular}

\section{Corresponding author}

Serena Galvani can be contacted at: s.galvani2@campus. uniurb.it

For instructions on how to order reprints of this article, please visit our website:

www.emeraldgrouppublishing.com/licensing/reprints.htm

Or contact us for further details: permissions@emeraldinsight.com 